て弁置換を決定したあのであった．第 2 の問題について は，機能的閉鎖不全に対して置換が行われた 4 例がとく に問題としてあげられる，そのうち 3 例は第 1 のポイン 卜で述べた確実性を期待したあので, 残る1例は，他の 二つの弁が置換を要したものの, 患者の年龄が 32 歳で, 術前の NYHA 分類であII度であったととより，形成 術で乗り切れたのではないかと考えられる．その他 3 例 において, 病変が軽度であり, 最近の弁形成の技術をむ ってすれば置換を行わなくてあよかった症例かもしれな い. 最後に, 術後合併症のひとつである血栓弁は1例 で, 生存例 16 例から考えると発生率は高いが, 使用す る弁の選択について考え㸚ばならない点であると思われ る. 1 例に房室ブロックを残したが，その他長期生存例
においていまのとてろ問題点はみられていない，

以上，主として機械弁である Björk-Shiley 弁を用い た三尖弁置換術は満足しうるあのであると考えるが, 文献的にみて, 三尖弁機能不全が軽度のものは放置, 高 度のものは置換術を行うという意見には賛同しうるもの の，中等度のものに対していずれを選択するかはまだ残 された問題である.

文 献 1) Carpentier, et al.: JTCS 67: 53, 1974 2) Breyer, et al.: JTCS 72: 867, 1976. 3) Grondin, et al.: JTCS 53: 7, 1967.4 4) Schoevaerdts, et al. : J. Cardiovasc. Surg. 18: 397, 1977. 5) Sanfelippo, et al.: JTCS 71: 441, 1976. 6) Jugdutt, et al.: JTCS $74: 1977.7)$ Duran, et al.: JTCS 80:849, 1980. 8) Bourdillon, et al.: Br. Heart J. 38: 1149, 1976.

56

\title{
後天性三尖弁閉鎖不全症に対する三尖弁輪形成術の 術後早期における超音波ドプラー法を用いた検討
}

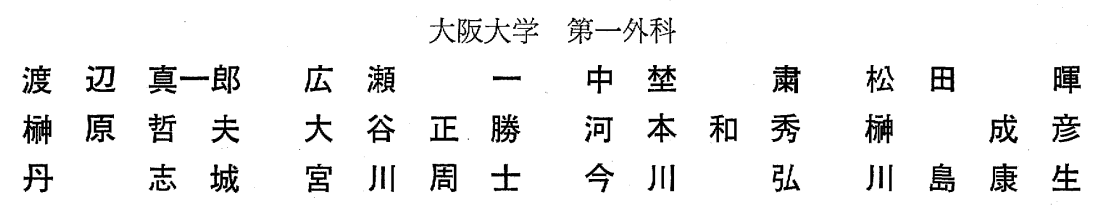

目的

僧帽弁疾患に伴った三尖弁閉鎖不全症 (TR) に対する 三尖弁輪形成術 (TAP) の効果に関して，てれまで術後 遠隔期における検討は多くなされているが，術後早期に おける検討はあまり行われていない，TAP はとくに術 後急性期にその効果を期するものであり，乙の時期にお ける検討は意義あるあのと考える. 今回，超音波パルス ドプラー法 (PDE) を用いて術後早期において TAP の 効果を左右する因子を検討した.

\section{対象}

1984 年 5 月から 1986 年 2 月までに僧帽弁手術に際し て TAP を施行した 19 例（MS 8例，MR 8例，A+ M 3 例) を対象とした. 平均年糩 48 歳（37〜63歳）, 性別は男 7 例，女 12 例であった，心電図上ではすべて 心房細動であった。

手術は MVR 17 例, OMC 1例, MAP 1例を施行
した，TAP は全例に Kay 法を施行し，経肺動脈三尖 弁逆流試験にて逆流がないか，あるいは無視できる程度 であることを術中に確認した。

\section{方法}

装置は Philips 社製二方向シネアンギオ Polydia-

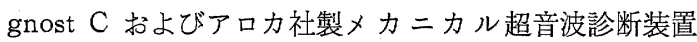
(SSD-720) およびドプラーユニット（UGR-23）を用い た. 術前心葴カテーテル検查および右室造影から血行 動態諸量, TR の程度, TR の逆流率 $(\mathrm{RF})$, 右心室容 積および三尖弁長軸径指数 (TVD) を求めた. 右心室 容積は二方向右室造影像から Dodge の area-length 法より求め, 島崎らの回帰式を用いて補正を行い, 右 室収縮末期容積指数 (RVESVI), 右室拡張末期指数 (RVEDVI), 右室一回拍出量指数 (RVSVI), 右室駆出 率 (RVEF) を求めた. TVD は右心室造影正面像また は側面像における三尖弁の negative valve shadow の 長軸径を測定しＵＵａgo らの方法にもとづき収縮期 
表 1 術前カテーテル検査

\begin{tabular}{lrcc}
\hline & & \multicolumn{1}{c}{ A群 $(n=9)$} & \multicolumn{1}{c}{ B群 $(n=10)$} \\
\hline C.I & $\left(l / \mathrm{mim} / \mathrm{m}^{2}\right)$ & $2.48 \pm 0.99$ & $2.18 \pm 0.45$ \\
RAm & $(\mathrm{mmHg})$ & $9.3 \pm 6.2$ & $8.0 \pm 5.6$ \\
RVDEP & $(\mathrm{mmHg})$ & $9.6 \pm 6.9$ & $7.9 \pm 5.2$ \\
PAm & $(\mathrm{mmHg})$ & $36.6 \pm 17.9$ & $34.3 \pm 15.6$ \\
PVR & $\left(\mathrm{dyn} \cdot \mathrm{sec} \cdot \mathrm{cm}^{-5}\right)$ & $271 \pm 183$ & $346 \pm 202$ \\
RVESVI & $\left(\mathrm{ml} / \mathrm{m}^{2}\right)$ & $95.2 \pm 36.0$ & $96.9 \pm 16.2$ \\
RVEDVI & $\left(\mathrm{ml} / \mathrm{m}^{2}\right)$ & $191.6 \pm 60.2$ & $180.2 \pm 34.5$ \\
RVSVI & $\left(\mathrm{ml} / \mathrm{m}^{2}\right)$ & $96.3 \pm 46.7$ & $83.4 \pm 23.7$ \\
RVEF & $(\%)$ & $49.3 \pm 13.0$ & $45.8 \pm 6.6$ \\
TVD & $\left(\mathrm{mm} / \mathrm{m}^{2}\right)$ & $43.6 \pm 7.1$ & $38.1 \pm 4.2$ \\
TVA & $(\%)$ & $2.9 \pm 3.2$ & $9.5 \pm 4.1 *$ \\
RF & $(\%)$ & $66.0 \pm 17.7$ & $62.7 \pm 13.7$ \\
\hline
\end{tabular}

$* p<0.05$

$\left(D_{\min }\right)$ ならびに拡張期 $\left(D_{\max }\right)$ における長軸径の変化 率 $\left[\mathrm{STA}(\%)\left\{\left(D_{\max }-D_{\min }\right) / D_{\max }\right\} \times 100\right]$ を求めた. 術 前および術後早期（3〜21日目，平均 9 日目）飞 $\mathrm{PDE}$ 法を用いて三尖弁口面加らの逆流シグナル最大到達距離 を測定した．TR の程度は宮武らの分類法を用いて，五 段階に分類した.

術後の PAm は 右室流出路の血流波形加ら Accelation time (ACT), RV ejection time (RVET) を測定 ᄂ, ACT/RVET 值を求打香らの式 [log 10 (PAm) $=-2.8(\mathrm{ACT} / \mathrm{RVET})+2.4]$ 上り求めた.

\section{成績}

僧帽弁疾患患者 42 例の $\mathrm{PDE}$ 法による TR の程度と 心臓カテーテル㭘査执よび右室造影から求めた $\mathrm{TR}$ 逆 流率の対比検討した結果, $r=0.73, p<0.01$ で有意の 相関が認められている.よって, PDE 法を用いて TAP 術前後における TR 程度の判定を行った，術後は術前 に比し有意に減少した $(p<0.05)$. 術後に 2 度以上の $\mathrm{TR}$ の残存を認めた症例が 9 例 (47.4\%)〔A群〕あり， TR が 1 度または消失した症例が 10 例 (52.6\%)〔B群〕 であった．術前の PDE 法による TR の程度および TR の逆流率に扔いては両群間代有意な差は認められなかっ た.

また術前の心係数 (C. I.), 平均右心房圧 (RAm), 右 室拡張末期圧 (RVEDP), 平均肺動脈圧 (PAm), 全肺血 管抵抗值 (PVR) においてはいずれ屯両群間に有意な差 は認められなかった。 また術前の RVESVI, RVEDVI, RVSVI，RVEF および TVD においては両群間に有意 な差は認められなかった。しかしながら，術前における STA をみるとA群 $2.9 \pm 3.2 \%$, B 群 $9.5 \pm 4.1 \%$ であ り，A群ではB 群に比し有意に低值であった $(p<0.05)$. 術後の PAm に扔いてはA群 $39.3 \pm 10.8 \mathrm{mmHg}, \mathrm{B}$ 群 $24.2 \pm 3.9 \mathrm{mmHg}$ であり両群間に有意差を認めた（ $p<$ $0.05)$.

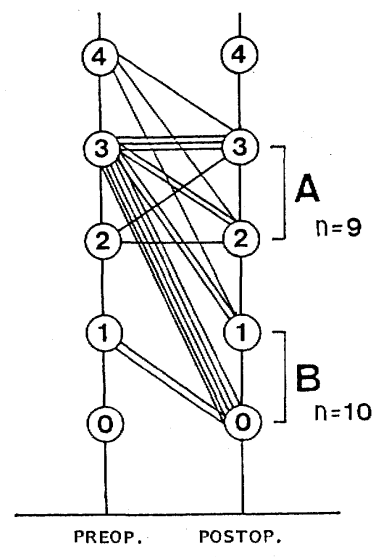

図 1 (a) 術前および術後早期に おりり TR の推移 by DOPPLER

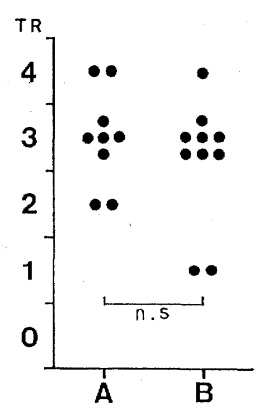

図 $1(\mathbf{b})$ 術前における TR 程度の 比較 by DOPPLER

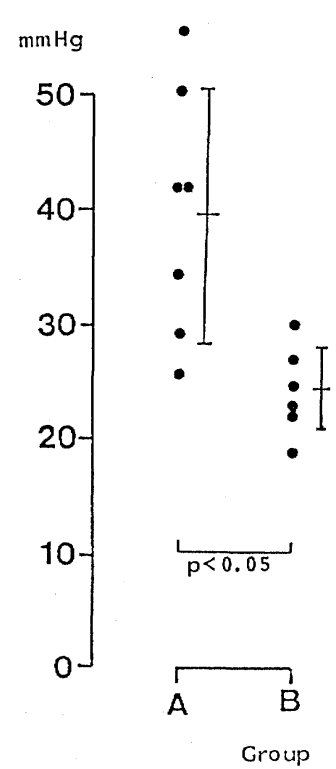

図 1(c) 術後早期 PAm by DOPPLER 


\section{考 案}

TAP の効果を左右する因子について術後遠隔成績か らの検討は多くされている．その因子として僧帽弁病変 の修復の良否, 心機能の回復程度および肺循環動態の術 後におりる改善の程度であると教室の中禁らは述べてい る.

しかしながら TAP は術後のクリティカルな時期にそ の効果を期するものであり僧帽弁手術の成績を左右する あのと考えられている.

そこで術後早期において TAP の効果を左右する因子 につき検討を行った結果, 次の二点につき有意差を認め た. 1）STA に括いて TR 残存例は消失例に比し低值 であった，2）術後に拉ける PAm は TR 残存例では 高值であった。

STA については TR 残存群 $2.9 \pm 3.2 \% \mathrm{TR}$ 消失群 $9.5 \pm 4.1 \%$ で両群ともにUbago らの報告した正常值 $(30 \pm 7 \%)$ に比し減少しており，また TR の残存した 症例は消失した症例に比し有意に減少していたＳTA に関して Ubago, Tei らが TR を有する症例は TR を 伴わない対象群に比較し心エコーおよび右室造影から三 尖弁の弁輪径, 弁輪周囲径および弁口面積の変化率にお いて減少していると報告している．よって術前の三尖弁 の弁輪径が変化していない TR 症例では Kay 法による TAP の効果は術後早期において期待できないと考えら れる.

次に TR 残存例では術後の PAm は高值を示した. これは僧帽弁疾患のさらに病期の進行した結果より, 器質的な肺血管病変は残存するため術後早期において
PAm は正常值に回復していないために TR が残存し たと考えられる.

よって術前に执いて肺血管病変の評価が重要である. しかしながら，術前の PAm および PVR については $\mathrm{TR}$ 残存例之消失例との間に拈いて差は認めなかった。 別種の手段により術前の肺血管病変の評価を行う必要が あると考える.さらに遠隔期も含めて検討し Kay 法に よる TAP の限界, 三尖弁置換術の適応につき検討した ().

結語

僧帽弁疾患に伴った三尖弁閉鎖不全症 (TR) に対する 三尖弁輪形成術 (TAP) の効果を左右する因子につき術 後早期における TR 残存例と消失例とを比較検討した 結果,

1 ) 術前の TR の程度, 肺循環動態, 血行動態諸量 および右室容積，三尖弁弁輪長軸径については両群間に 有意差を認めなかった,

2 ) 術前の三尖弁弁輪長軸径の変化率は TR 残存例 では TR 消失例に比し有意に低值であった $(p<0.05)$ ，

3 ) 術後の平均肺動脈圧は TR 残存例では TR 消失 例に比し有意に高值であった（ $p<0.05)$.

文 献 1) Kay, J. H.：Ann. Surg. 162：53, 1965. 2) Kawashima, Y.: Jpn. Circ. J. 38: 835, 1974.3 3) 中埜 肃：胸部外科 $28: 609,1975.4)$ 島崎靖久: 心藏 11: 163, 1979. 5) 中埜 肃：日胸外会誌 $28: 20,1980$. 6) Miyata ke, K.: Circulation 66: 777, 1982. 7) Kitabatake, A.: Circulation 68: 302, 1983. 8) Tei, C.: Circulation. 66 665, 1982. 9) Ubago, J. L. : Am. J. Cardiol. 52: 305, 1983. 10) 岸本英文：心臟 17：711，1985.

\section{7 三尖弁閉鎖不全症の $2 \mathrm{DD}$ による評価と tricuspid annuloplasty (Carpentier ring)}

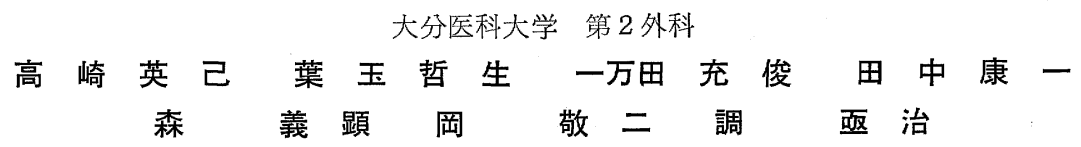

1981 年 10 月以来, 連合弁膜症症例で, 三尖弁閉鎖不 全症 (TR) を合併した 18 例を対象に, 術後平均 19 力月 の経過観察より三尖弁手術の檢討を行った.

従来, 三尖弁輪形成術 (TAP) の適応は, 平均右房
圧，右室造影，Contrastecho 等を参考化術中の右房へ の逆流 jet が 1 横指幅を越えるものとしてきた. 1984 年 以降は, TR の診断に, 2 Dimensional Doppler Echocardiography (2 DD) を使用している. non invasiveな 